\title{
Urban Ecosystem Services Quantification through Remote Sensing Approach: A Systematic Review
}

\author{
Paulo Amador Tavares ${ }^{1, *} \mathbb{D}$, Norma Beltrão ${ }^{1} \mathbb{D}$, Ulisses Silva Guimarães ${ }^{2} \mathbb{D}$, Ana Teodoro ${ }^{3} \mathbb{D}$ and \\ Paulo Gonçalves ${ }^{1}$ (1) \\ 1 Postgraduate Program in Environmental Sciences, State University of Pará (UEPA), 66095-100 Belém, Brazil; \\ normaely@uepa.br (N.B.); paulogoncalves@uepa.br (P.G.) \\ 2 Operations and Management Center of the Amazon Protection System (CENSIPAM), 66617-420 Belém, \\ Brazil; ulisses.silva@sipam.gov.br \\ 3 Earth Sciences Institute (ICT) and Faculty of Sciences (FCUP), University of Porto, 4169-007 Porto, Portugal; \\ amteodor@fc.up.pt \\ * Correspondence: paulo.tavares@uepa.br; Tel.: +55-919-8070-6429
}

Received: 23 April 2019; Accepted: 7 May 2019; Published: 9 May 2019

check for updates

\begin{abstract}
Urban ecosystem services (UES) is an essential approach to the development of sustainable cities and must be incorporated into urban planning to be able to improve humans' life quality. This paper aimed to identify remote sensing (RS) data/techniques used in the literature in five years (2013-2017) for UES investigation and to analyze the similarity between them. For this purpose, we used the Scopus database of scientific journals, and a set of appropriate filters were applied. A total of 44 studies were selected, being $93.18 \%$ of them located in the Northern Hemisphere, mostly in Europe. The most common dataset used was the secondary data, followed by the Landsat family products. Land use and land cover (LULC) was the most common approach utilized, succeeded by radiometric indexes and band related. All four main classes (provision, regulation, supporting, and cultural) of ecosystem services (ES) were identified in the reviewed papers, wherein regulating services were the most popular modality mentioned. Seven different groups were established as having $100 \%$ of similarity between methods and ES results. Therefore, RS is identified in the literature as an important technique to reach this goal. However, we highlight the lack of studies in the southern hemisphere.
\end{abstract}

Keywords: urban planning; urban land cover; spatial analysis; urban forest; satellite data; human well-being; urbanization

\section{Introduction}

Ecosystem services (ES) are described as the processes, conditions, and benefits provided by nature to maintain and fulfil the human needs and are commonly subdivided into four main classes of services: (i) Provision; (ii) Regulation; (iii) Supporting and; (iv) Cultural [1-3]. All these classes can be represented by at least 17 different types of ES with a total estimated value of about \$33 trillion on average [1].

The ES supply depends on biophysical factors and their modifications over time and space [4-7]. Since ES are the benefits that humans acquire directly or indirectly through nature [2,8], the urban environments are important study areas for ES supply and demand analysis, once it is where most of the users and beneficiaries of the ES live [7,9-11]. The incorporation in quantity, quality, and diversity of ES increases the socioecological resilience of urban areas, changing the spatial distribution of the main natural coverages that produce ES [12]. In this context, the preservation and restoration of natural environments within urban areas is socio-environmentally necessary and, commonly, economically viable [13]. Thus, mapping urban ecosystem services (UES) is described in the literature 
as an opportunity to monitor natural and anthropized areas that provide ES (its identification and classification), verify how this provision changes according to time and space $[5,6,9,14,15]$, and assess how human-driven changes impacted the urban areas, positively or negatively [7,16,17].

Previously literature reviews on UES have found key challenges and insights for future research $[18,19]$. These papers agreed that the current studies about this subject have some lacks when they are analyzed under the interdisciplinary context and usually have limitations when interpreted under spatial coverage. Some other reviews that consider the remote sensing (RS) of the ES variables, showed that even though RS is not the perfect solution for understanding and monitoring ES, it has the potential to comprehend and improve the quality of the work anywhere in the world, as long as the correct tool is chosen [20,21]. However, all reviews acknowledged here, which considered the spatial distribution of the papers assessed, show that the main part of RS studies of ES and UES variables are concentrated in the Northern Hemisphere [10,18,22].

A key aspect of UES mapping is to locate and identify environmental variables responsible for ES functioning. Aspects related to the temporal dynamics of UES have also been mentioned in the literature, such as the vegetation structural attributes [23] and the change in provision of UES [15,23,24]. Existing research [25-27] has already emphasized the role played by RS data/techniques in enhancing ecological studies given the number of open access data and software available for this purpose [27]. Its potential is still greater when considering data sources with daily images [28], especially for tropical regions with high cloud coverage [29]. Furthermore, RS is highlighted for several authors as an efficient method for urban green spaces [30,31], land use land over (LULC) [32-36], and urban heat islands analyses [24,37,38]. However, current RS methods can vary greatly. For instance, different applications include the LULC change detection [39] and forest disturbance history [40], data fusion of optical and radar data for precisely machine learning supervised mapping of LULC [41,42], the evaluation of water quality index with machine learning algorithms [43], the use of ALOS-2 PALSAR-2 and Sentinel-2A imagery to estimate aboveground biomass [44], and the use of synthetic aperture radar (SAR) and light detection and ranging (LiDAR) data to evaluate the flood depth through the application of a normalized difference index [45].

Understanding how ecological studies involving RS data/techniques can relate different areas and apply different methodologies is; therefore, an issue of great interest in UES identification, classification, and modeling. Conceptually, the outcomes obtained from UES studies are linked to the human well-being and its close relationship with nature [46,47]. From a global point of view, researchers must contribute to the efforts of United Nations (UN) to promote the development of sustainable cities and communities (Sustainable Development Goal, SDG 11) until 2030 [48-52]. Thus, RS data/techniques turns the findings of ES studies more relevant [53], more adequate to urban planning, and able to guide for sustainable development in these areas [13,54-57].

Therefore, by considering the importance of identifying, classifying, and modeling ES in urban environments, as well as the recent developments achieved by the RS data/techniques, the objectives of this work are: (i) To analyze, through a literature review, how researchers are interpreting results from RS data/techniques under a UES perspective; (ii) to identify the methodologies and databases used and; (iii) to analyze the similarities and differences between the studies.

\section{Materials and Methods}

In order to evaluate and interpret the available and relevant research developed under the topic UES by using RS data/techniques, a systematic literature review was carried out [58,59]. Thus, to present the state of art of the suitability of RS data/techniques to identify, classify, and model UES, a was conducted survey covering five full years of research on this topic, starting from January 2013 until December 2017.

Scopus bibliographic database was chosen to identify these papers. Scopus has a broad coverage with more than 22,000 titles from over 5000 international publishers. This indexer has functional tools for acquiring relevant documents, besides providing them in different ways and covering research areas 
that are relevant to the keywords chosen [60]. The Scopus platform contains results refinement tabs that offers several types of filtering options, which are (i) Access type; (ii) Year; (iii) Author name; (iv) Subject area; (v) Document type; (vi) Source title; (vii) Keyword; (viii) Affiliation; (ix) Funding sponsor; (x) Country/territory; (xi) Source type; and (xii) Language. These options support the appropriate choice of relevant scientific articles. For these reasons, Scopus is mentioned in the literature as a trustable tool for identifying relevant papers [60-63].

In this work, we chose published scientific journals and relevant conference papers, both were selected using the Scopus database, as it was provided by the education institute where this analysis was carried out. We selected three different sets of keywords, which were chosen in previous analysis of relevant articles to the UES study. These sets of keywords were (a) "Satellite," "Ecosystem Service," and "Urban"; (b) "Mapping," "Ecosystem Service," and "Urban"; and (c) "Remote Sensing," "Ecosystem Service," and "Urban." Moreover, this literature survey considered the following subject areas: (1) Environmental science; (2) agricultural and biological science; (3) social science; (4) Earth and planetary science; (5) decision science; (6) engineering; (7) physics and astronomy; and (8) economics, econometrics, and finance. These subjects were selected as they can be related, in some level, to the scope of this work.

We have further defined some exclusion criteria, which are mentioned, in order, as follows: (i) Removal of duplicate results in the identification section; (ii) in the screening segment, by reading the abstracts, we removed studies that did not use RS applications, nor were UES studies, and studies that did not involve only urban areas; (iii) in the eligibility section, we verified, by assessing the full body of the text, the information described in the exclusion criteria number (ii).

The results found were arranged in three main classes: (1) Database; (2) method; and (3) types of ES considered. To better understand the similarity between the techniques used and the types of results found in each study, we performed a multivariable statistical analysis, and a dendrogram was produced for visualizing the result, as mentioned by Booth et al. [64] as an important approach for systematic reviews.

Figure 1 illustrates the flowchart of the processing analyses performed. In the identification step, only duplicated data were removed. For screening, we read the abstracts and excluded the ones not related to our scope. Then, the full-text analysis was done, and 44 studies from the initial 215 were included in both qualitative and quantitative analysis.
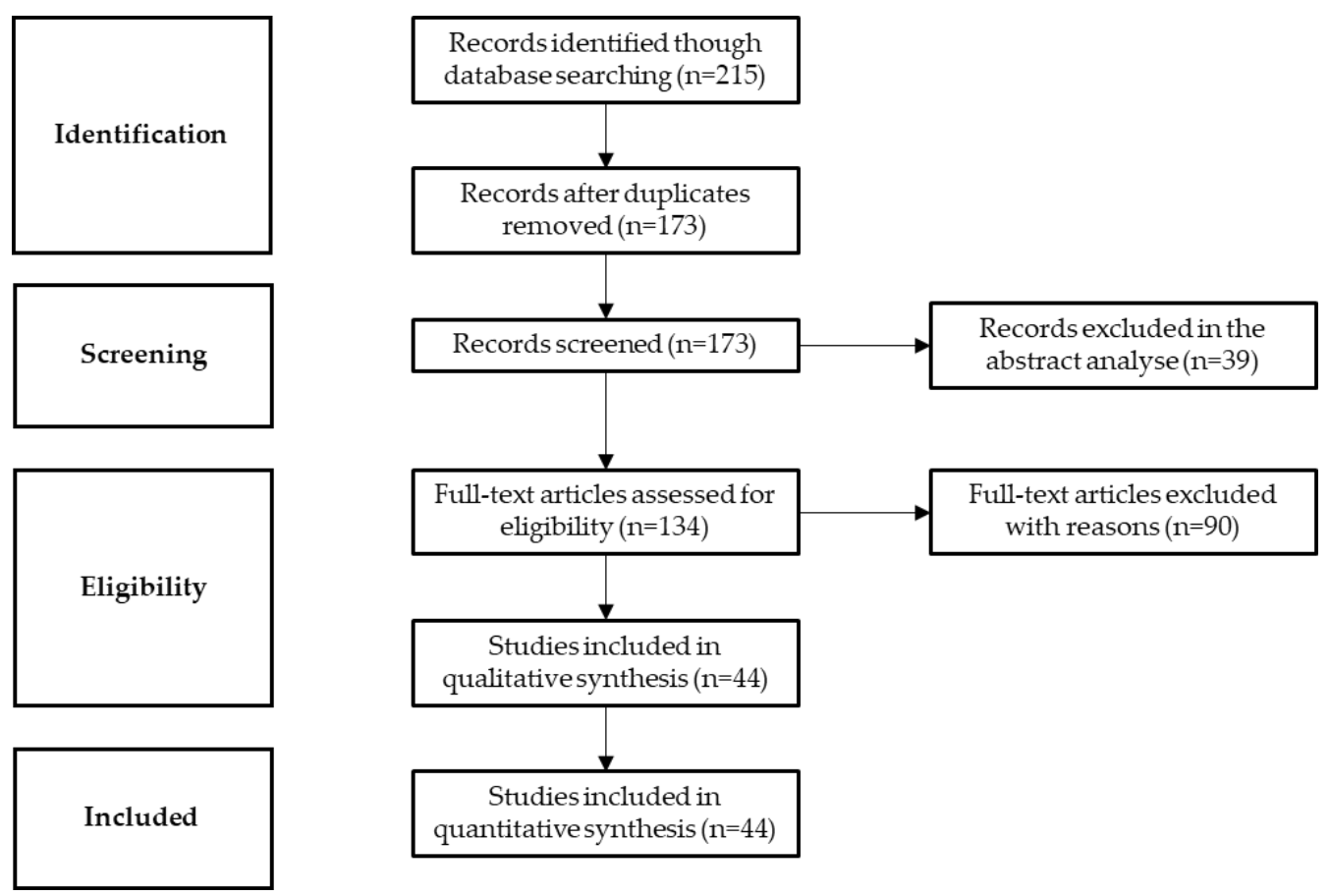

Figure 1. Steps adopted for this research purpose. 


\section{Results}

A total of $44(20.46 \%$ of the total) papers were analyzed in both quantitative and qualitative investigation. This number is considered a low quantity for systematics literature reviews. Hence, we highlight that a small amount of studies relating RS data/techniques with UES approaches were produced during the period analyzed. All these articles were manually reviewed in order to ensure that they were truly applications of RS data/techniques for UES approaches.

The Earth's Northern Hemisphere accounted for most of the studies $(93.18 \%)$, mainly located in Europe (52.27\%), followed by China (15.90\%), and USA (13.63\%). The South America countries represented the Southern Hemisphere with $6.81 \%$ of the total. The Asian countries were also important contributors to the overall number of studies (25\%) — as mentioned, mainly located in China $(63.63 \%$ of Asia's contribution). The map in Figure 2 illustrates the spatial distribution of the papers assessed.

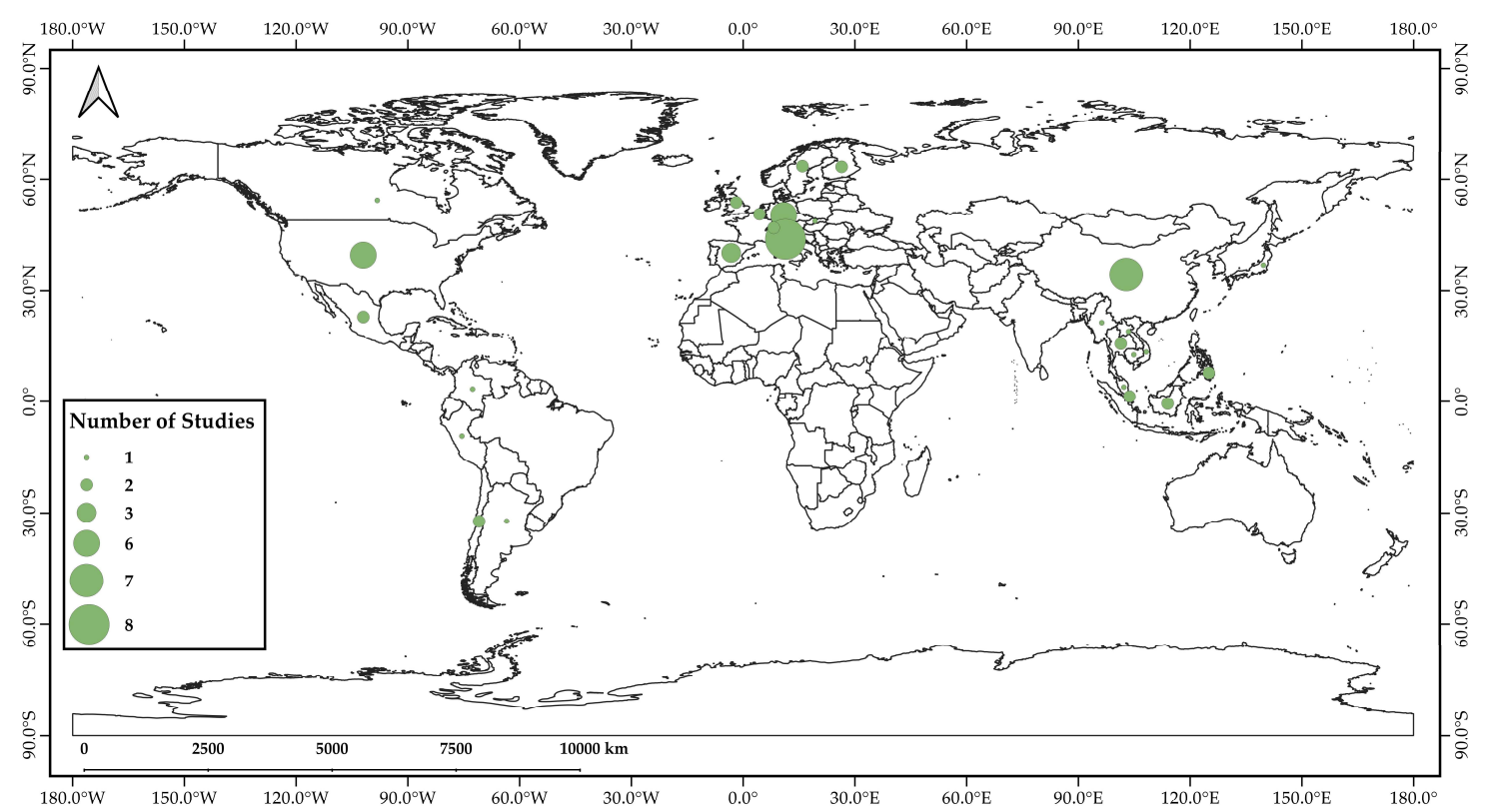

Figure 2. Spatial distribution of the papers considered in our study. Some of the papers assessed used more than one country as a study area, so we added one value for each country.

The studies assessed were distributed along six years according to the following percentages: 2013 (4.55\%), 2014 (18.18\%), 2015 (9.09\%), 2016 (22.73\%), and 2017 (45.45\%). In this range, it is possible to identify a slight tendency in the increase in the numbers of UES papers published during these years, something that did not happen only in the year 2015, when the number of published articles was lower than in 2014. Largely, 2017 was the major contributor, indicating an increasing trend for research involving ES for urban areas sustainable development.

Figure 3 illustrates that, for the selected studies, the most used primary data (Landsat family) were costless. Usually, secondary data are also costless and appear to be widely employed in UES studies, especially those related to LULC mapping, which were highly mentioned. 


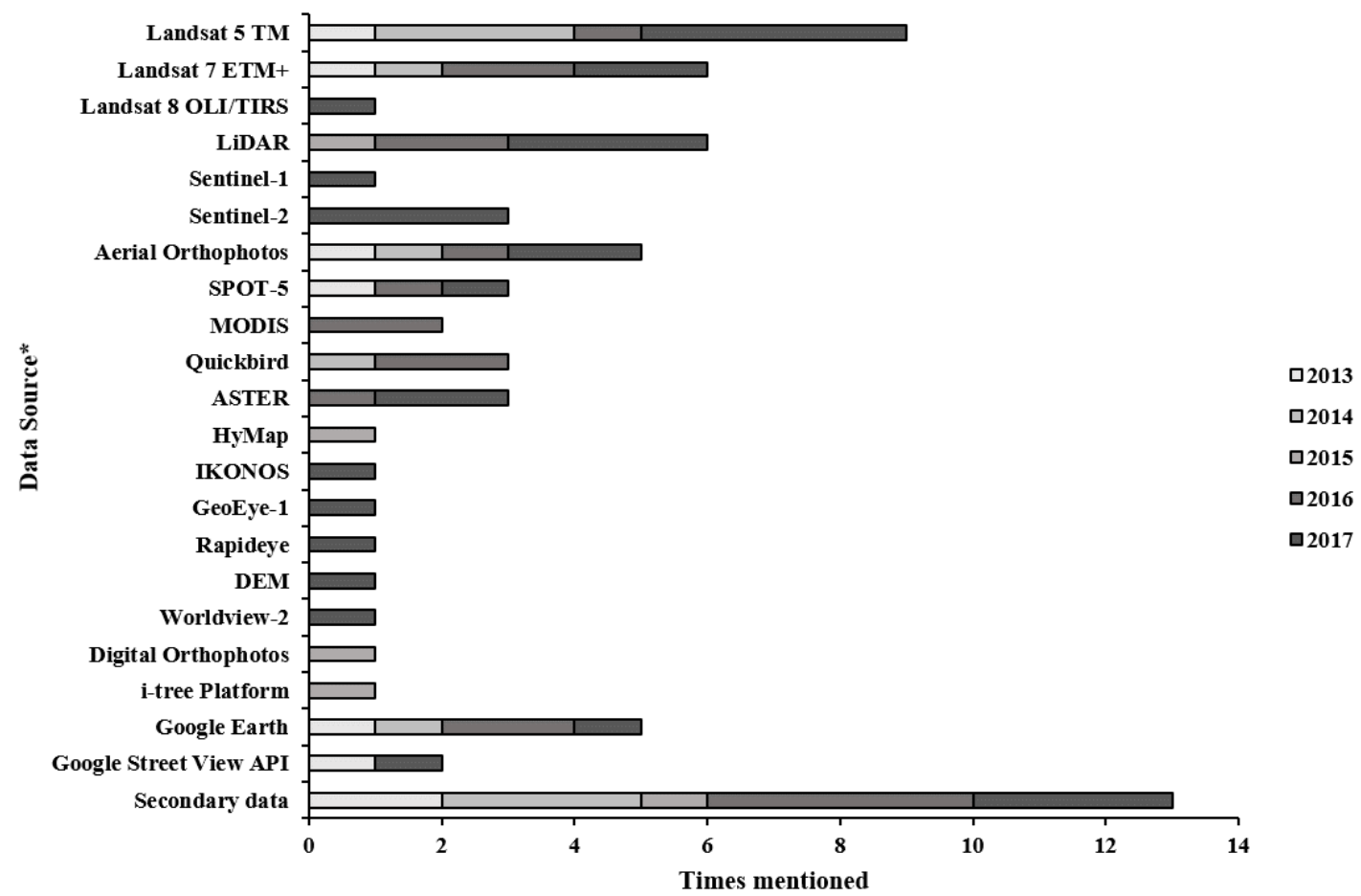

Figure 3. Identification of data source used by the authors, separated by year (2013-2017). * Abbreviations mentioned in the data source axis stands for TM, thematic mapper; ETM+, enhanced thematic mapper plus; OLI/TIRS, operational land imager/thermal infrared sensor; SPOT, satellite pour l'observation de la Terre; MODIS, moderate-resolution imaging spectroradiometer; ASTER, advanced spaceborne thermal emission and reflection radiometer; DEM, digital elevation model; API, application programming interface.

With regards to LULC secondary data, the information extracted from these were related with zoning plans [65], urban atlas [16], soil maps [66], high ecological resolution classification for urban landscape and environmental systems (HERCULES) [33], census data [67], and information regarding naturalness and natural protected areas [68].

The Google Earth images, another free and open access data source, were used by the UES authors for LULC purposes and for validation analysis of supervised and unsupervised classification algorithms [33,69-71]. Similarly, the Google Street View API was used for understanding the urban green canopy cover, while Google Street View photos, for instance, were used to determine the green canopy cover in different locations of Singapore [72].

In the methodological analyses (Figure 4), the most cited methodology was the LULC (75\%), followed by the normalized difference vegetation index (NDVI) with 15.91\%, leaf area index (LAI) $(11.36 \%)$, and land surface temperature (LST) $(11.36 \%)$. Some methods were mentioned only once (2.27\%): normalized difference green-building volume (NDGB), green canopy cover, ES Index, modified normalized difference water index (MNDWI), and visible red and NIR-based built-up index (VrNIR-BI). The biomass estimation in urban areas, the species mapping, and the modeling of carbon assessment (MOCA) flux model were cited in $4.55 \%$ of the papers selected.

Urban trees mapping methodology was mentioned as one useful approach for understanding and regulating services [73-76] and supporting services [76]. Such mapping usually uses high-quality images as aerial orthophotos [73,74] and LiDAR [75], since its accuracy is essential to identify the tree coverage in urban areas.

The UES index methodology was mentioned only once in the selected papers [32]. However, it is important to highlight that results found in that study delivered a more consistent approach on UES importance as well as ES supply and demand in the urban scenario. Such finding seems to be a robust tool to instantly propose suggestions for urban planning and development of sustainable cities. 


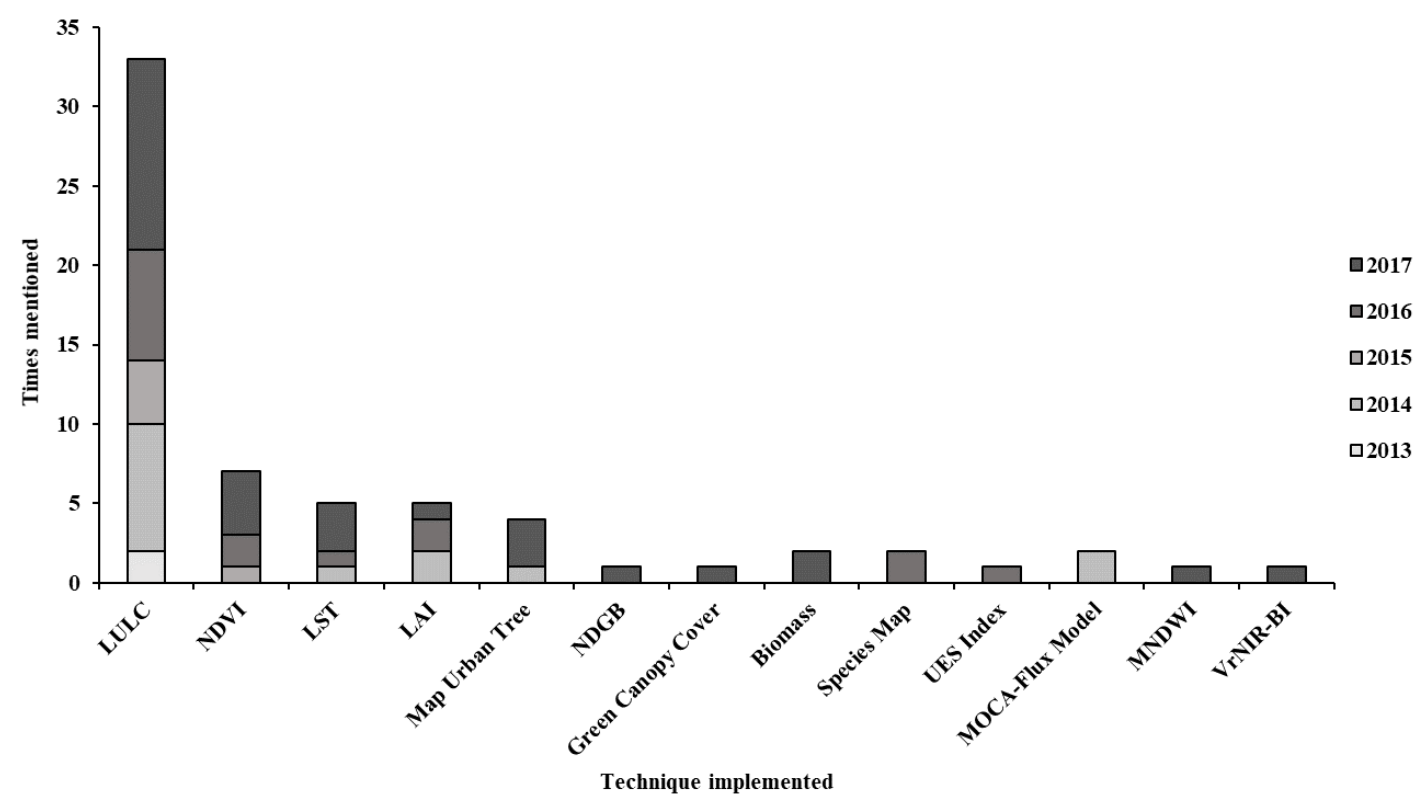

Figure 4. Methods implemented by the authors to infer UES results, separated by year (2013-2017).

Figure 5 summarizes the four main ES groups (Provisioning, Regulating, Supporting, and Cultural) identified in the literature review and their ES subtypes. Additionally highlighted, in a separated category, is the urban green spaces.

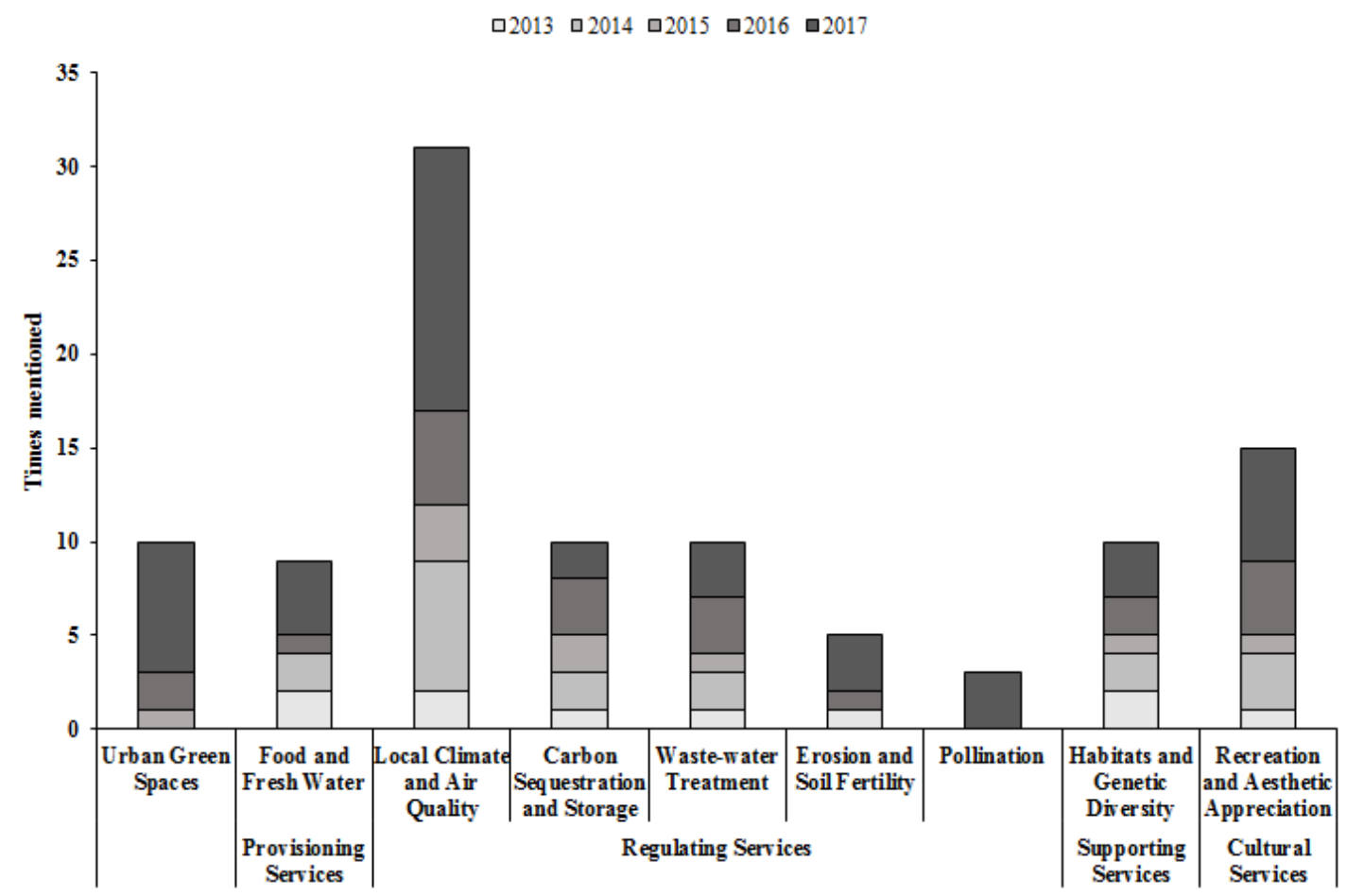

Figure 5. UES identified in the literature reviewed, separated by year (2013-2017).

All the four main classes of ES described by Costanza et al. [1] and TEEB [2] were found in the selected studies. The ES types mentioned in all five years considered were: local climate and air quality $(70.45 \%)$, carbon sequestration and storage and wastewater treatment $(22.73 \%)$ for regulating types of services habitats and genetic diversity $(22.73 \%)$ for supporting services, and recreation and aesthetic contemplation $(34.09 \%)$ representing cultural services. 
The most mentioned regulating services identified were, generally, extracted by the direct interpretation of spectral indexes related to ecological components [77]. In contrast, other regulating services, such as erosion, soil fertility, and pollination, would only be estimated using factors and coefficients throughout data interpretation $[67,71]$.

Supporting services (habitats and genetic diversity) and cultural services (recreation and aesthetic contemplation) were generally obtained by interpreting urban green coverage and identifying significant localities for maintenance of local species of fauna and flora, as well as social interactions and social life, respectively $[76,78,79]$. The provision services were only related to fresh water and food supply which were identified through water bodies and urban agriculture in urban and peri-urban localities and mainly related to urban green coverage $[9,16,33,65,67,79-82]$.

Urban green spaces were considered in a different column, because its presence (natural or human-made) can be related to the provision of bundles of ES, having positive effects on people's living and buildings' monetary values situated in the neighborhood [9,23,69,70,83-88].

Another parameter considered in this literature review was the similarity of methodologies and the UES estimated in the selected papers. The dendrogram shown in Figure 6 illustrates the findings of cluster analysis. In Figure 6, two main clusters were created (which had $0 \%$ of similarity between them and were divided in the components $\mathrm{A}$ and $\mathrm{B}$. The difference between them was mostly related to the type of UES identified. In group B, there was a higher number of UES types identified, when compared with group A. Group B was the only one with recreation and aesthetic appreciation services, food and fresh water provision, and pollination services identified. On the other hand, group A had their researchers mostly considering local climate regulation and urban green cover. By dissociating the groups from the methods used, we noticed that group A was more diverse than group B, but LULC was the most common methodology implemented.

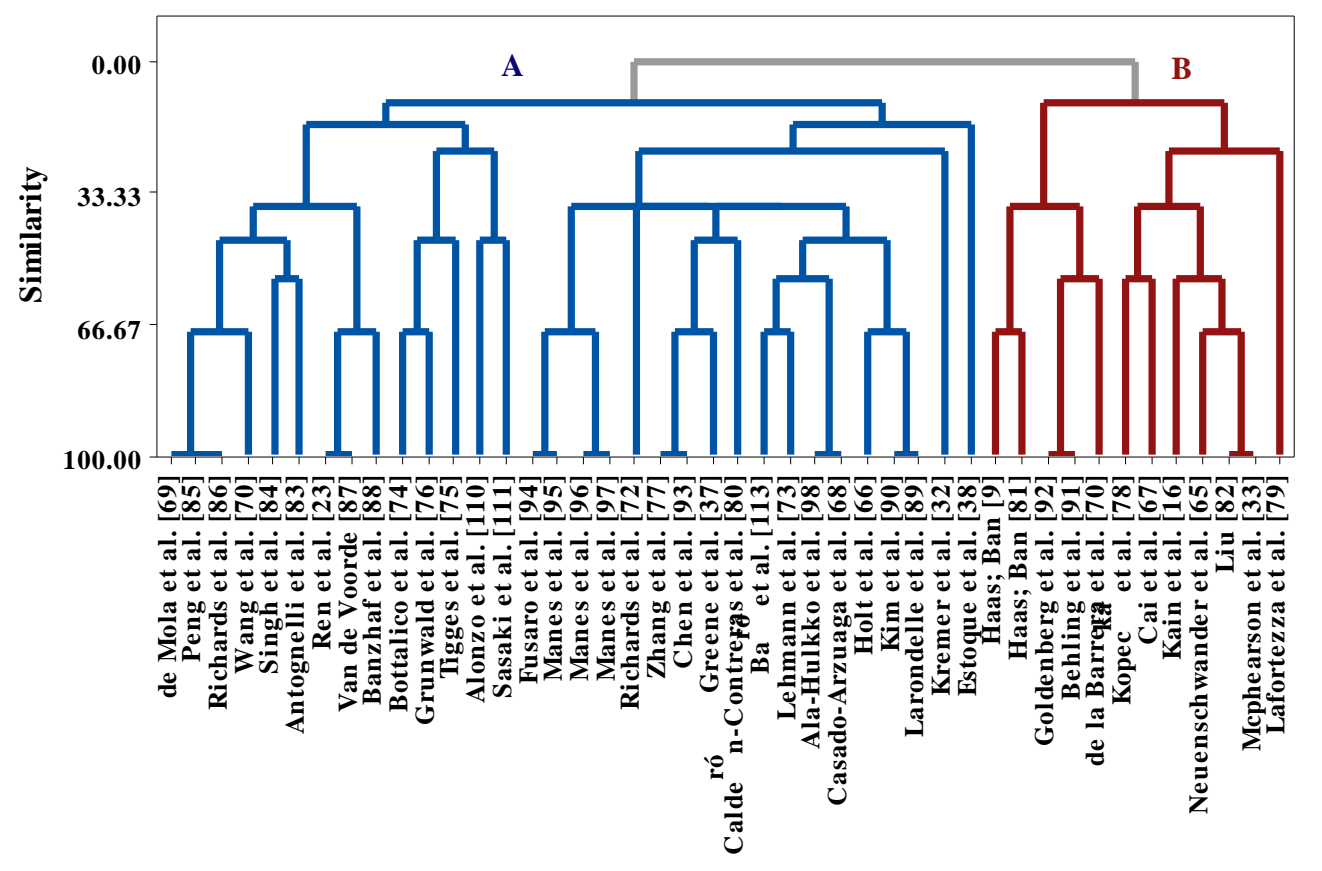

Figure 6. Cluster analysis of the similarity between the methodologies used and the UES identified, the full body papers investigated are expressed according to the order of appearance in the body of the text Clusters were divided into two groups with more than $0 \%$ of similarity, group A (blue interactions) and group B (red interactions).

De Mola et al. [69], Peng et al. [85], and Richards et al. [86] developed LULC methodologies for mapping urban green spaces. It is noteworthy the different approaches of obtaining LULC information, 
since all authors used different data sources in their studies: Google Earth data [69], ASTER, Landsat 7 ETM+ and Landsat 5 TM imagery [85], and only Landsat 7 ETM+ imagery [86].

The papers published by Van de Voorde [87] and Ren et al. [23] used NDVI to identify urban green spaces. However, findings from [86] suggest that its results, using Quickbird high spatial resolution satellite imagery, were more accurate than those obtained by [23], which used a $30 \mathrm{~m}$ resolution free data source Landsat $5 \mathrm{TM}$.

Larondelle et al. [89] and Kim et al. [90] studied the same type of UES by using the same method, as noticed in Figure 6. These authors chose the LULC method and had their results based on regulating services-local climate and air quality, and carbon sequestration and storage. Similarly, Behling et al. [91] and Goldenberg et al. [92] also chose the same type of methodology to identify the same range of UES. In their method, regulating services were the focus of the study, but LULC was also selected. Nonetheless, the services considered were local climate, air quality, and wastewater treatment.

For the estimation of local climate and air quality regulation services only, three $100 \%$ similar groups were identified: (i) Chen et al. [93] and Zhang et al. [77], both studies used LST and LULC (similarly to them, Greene et al. [37] used the same techniques plus NDVI (commonly used for LST estimation purposed) to derive the same UES estimative); (ii) Fusaro et al. [94] and Manes et al. [95] used LULC and LAI; and (iii) Manes et al. [96,97], used the same types of methods of Fusaro et al. [94] and Manes et al. [95] and added the MOCA (modeling of carbon assessment) and flux model to identify local climate and air quality regulating services.

Ala-Hulkko et al. [98] and Casado-Arzuaga et al. [68] also chose LULC as methodology. These papers found the cultural services of recreation and aesthetic opportunities as results. The data source selected by these authors was the secondary data, since, for recreation and aesthetic purposes, to understand the local objectives and concerns is important as the feature's identification.

From all papers assessed with 100\% of similarity, Liu [82] (China) and Mcphearson et al. [33] (USA) were the ones with more UES estimations. Both studies used LULC as the only methodology. They estimated the four main classes of ES: (i) Provision (food and fresh water); (ii) Regulating (local climate and air quality, carbon sequestration and storage and waste-water treatment); (iii) Supporting (habitats and genetic diversity), and iv) Cultural (recreation and aesthetic appreciation).

\section{Discussion}

A large concentration of UES studies in the Northern Hemisphere was also found by Haase et al. [10] for UES and for ES in Barbosa et al. [22]. The results concentrated in the Northern Hemisphere confirm that a lack of studies exist in the Southern Hemisphere for sustainable development of cities, when compared with the ones in developed countries [48,51,99], and we could confirm that in our systematic review. However, the number of studies in Asia exceeding the number of studies in the USA, contrasts with what was presented by Haase et al. [10], which shows an interesting trend in the region in terms of UES.

We found that secondary data was the most used data source close agreement with the literature concerning the idea that RS facilitates ecological studies given the low-cost investments needed to study natural phenomena $[27,100]$. The Landsat and Sentinel satellite families are some of the most cited satellite source images. These are related to the easy access and availability in platforms such as the United States Geological Survey (USGS) and the Copernicus Sci-Hub from the European Space Agency (ESA) [101]. The data aggregation of Landsat and Sentinel constellation provides an Earth observation status with a revisit interval of 2.9 days, which is a perfect scenario for monitoring environments and their ES [102].

High resolution imagery, such as SPOT-5 [70,80], aerial and digital orthophotos $[73,74,88]$ Worldview-2 [79], RapidEye imagery [75], GeoEye, IKONOS [81], Quickbird [70,87,93], and HyMap [91] are considered more trustable and accurate resources for UES evaluation. However, these data are generally related to the researcher level of data access and research funding, since this type of high-quality imagery usually has a high acquisition cost. 
Recently, the United States (US) Government started to consider charges introduction to USGS data acquisition, including the Landsat family [103]. This might bring impacts on the LULC studies and deforestation monitoring in critical ecosystems in the world and consequent effects on UES studies, since most have used free source data up to now. The combination of different datasets is also an important alternative to the monitoring of difficult areas, such as the rainforest where the cloud coverage is commonly elevated [104,105], which may be a good alternative for tropical countries, facilitating further studies of UES for many countries in the Southern Hemisphere.

Among several methodologies surveyed, LULC was the only cited in all years. As mentioned, LULC is obtained from several types of techniques and different data sources, including data extracted directly from secondary data. Machine learning (ML) techniques, such as random forest (RF), support vector machine (SVM), and artificial neural networks (ANN) are tended towards for the LULC classification and identification of ecological variables. The accuracy of the methods is increasing along with the diversity in its modes of application, this is because of the popularization of the techniques [41,42,106-109], even for UES studies [9,69,81,82].

One factor that stimulates researchers to use LULC techniques to UES identification and classification purposes is that some authors describe the evaluation of each land use type. For instance, the work of Burkhard et al. [7], and the ESMERALDA project [6], is highly mentioned since it comprehends a description of how to evaluate ES from the CORINE land cover classification, which by itself considers 44 different types of land use and cover. From the interpretation of this paper, it is possible to perform the evaluation and modeling of other classifications simpler or that derivate from the CORINE land cover map $[9,16,73,81,82,98]$.

LULC has the advantage of being a product that is more easily understood by readers; however, radiometric indexes calculation (such as NDVI, LAI, NDGB, and MNDWI), and methodologies directly related with interpretation of sensor's data, produces more accurate and well-defined results, strictly based on band math, irrespective of human interpretation $[38,78,94]$. These indexes have been used in some papers to increase the LULC accuracy from ML techniques [42,108].

Unlike the studies with 100\% similarity presented in the results section, and by comparing the studies of Tigges et al. [75], Alonzo et al. [110], and Sasaki et al. [111], we observe that their results were not in line with those from the other papers reviewed, but all of them produced satisfactory results in their analysis. Tigges et al. [75] suggested the use of the urban trees mapping methodology to identify carbon sequestration and storage services. To this end, Alonzo et al. [110] used LAI and species maps, whereas Sasaki et al. [111] used species maps to assess carbon sequestration and storage, and habitats and genetic diversity results, respectively. This diversity of applications shows that there is a range of RS applications that can be used to reach similar products, demonstrating the importance of RS to the ecological variables, as Kwok [27] proposed it.

The UES index provided by Kremer et al. [32] was the only study, to present, no similarity with others. An explanation would be that their study incorporates a vast range of ES to produce a result reasoned in one value per pixel. Despite its unique methodology, this paper suggests an impressive simulation for urban scenarios by identifying precisely what city areas have more supply or demand for ES. An UES index was also proposed for Alam et al. [112], where several ES were selected as indicators and weighted through a SWOT (strengths, weaknesses, opportunities, threats) analysis; however, this paper was not found in the scope made for this systematic literature review. Baró et al. [113] also considered several indicators of ecosystem services to have a greater understanding of the UES capacity, flow, and demand; however, they do not develop an index to include all these results in one value.

\section{Conclusions}

In this work, the range of RS applications from the UES perspective was analyzed. Most of the UES studies examined here were concentrated in Northern Hemisphere sites, drawing attention to the need for additional UES studies and scenarios analysis in developing countries. In such regions, science investments are scarce, and; therefore, the use of RS methods with free and open data sources 
is an option, since the data source most mentioned in the surveyed studies are available for free. As a result, we highlight the importance of free data access for RS purposes, especially from the perspective of developing countries.

Among the benefits of using secondary data for UES studies, it appears as being the cheapest and most accessible alternative to estimate ES per area unit using trustable data. For instance, most of the studies, which considered cultural services, were able to estimate the provision of ES with a high degree of quality. In addition, official data previously validated can reduce costs related to ground truth observations and measurements.

LULC was the most mentioned methodology from those surveyed. Radiometric indexes and data able to be extracted directly from bands math, such as NDVI and LST, were also mentioned a few times. These indexes and band derived estimations are a way of having reliable data (once images are correctly pre-processed) without human interference.

All core classes of ES, described in the classic literature of ES, were mentioned for urban environments in the sample assessed. Regulating services showed a vast range of methodologies used to identify the benefits that urban green areas have to regulate local climate, as well as to estimate the amount of carbon captured and stored in the urban forest.

The similarity test for the studies assessed demonstrated that there is no standard procedure for producing or reproducing RS techniques in UES analyses, because the methods can vary according to the dataset used and their quality, the type of ES evaluated, and the researcher's experience.

In summary, it was possible to identify a vast range of data sources, techniques employed, and ES classification. The findings indicated plenty of opportunities for reproducing methodologies for UES, suggesting that the RS methods still have, in all countries, a valuable perspective for people to work with. Finally, this review found evidences that UES identification through RS data/techniques provides opportunities for scientists to conduct an array of environmental studies able to help countries to achieve, by 2030, the SDG 11 related to the development of sustainable cities. Countries, states, and municipalities in the development of more environmentally friendly public policies could discuss results from these studies.

Author Contributions: Conceptualization, P.A.T., N.B. and U.S.G.; methodology, P.A.T., N.B., U.S.G., A.T. and P.G.; software, P.A.T. and P.G.; formal analysis, P.A.T., N.B., U.S.G. and P.G.; investigation, P.A.T., N.B., U.S.G. and A.T.; writing-original draft preparation, P.A.T. and N.B.; writing-review and editing, P.A.T., N.B., U.S.G. and A.T.; supervision, N.B., U.S.G. and A.T.; project administration, P.A.T. and N.B.; funding acquisition, N.B.

Funding: This research was funded by CAPES-Coordenação de Aperfeiçoamento de Pessoal de Nível Superior grant number 1681775.

Acknowledgments: We thank CENSIPAM and UEPA for providing physical infrastructure for the development of this research. We would also like to thank the anonymous contributions of the reviewers of this paper.

Conflicts of Interest: The authors declare no conflicts of interest.

\section{References}

1. Costanza, R.; Arge, R.; Groot, R.D.; Farber, S.; Grasso, M.; Hannon, B.; Limburg, K.; Naeem, S.; O’Neil, R.V.; Paruelo, J.; et al. The Value of the World's Ecosystem Services and Natural Capital. Nature 1997, 387, 253-260. [CrossRef]

2. TEEB. TEEB Manual for Cities: Ecosystem Services in Urban Management; TEEB: Geneva, Switzerland, 2011.

3. Costanza, R.; de Groot, R.; Braat, L.; Kubiszewski, I.; Fioramonti, L.; Sutton, P.; Farber, S.; Grasso, M. Twenty years of ecosystem services: How far have we come and how far do we still need to go? Ecosyst. Serv. 2017, 28, 1-16. [CrossRef]

4. de Araujo Barbosa, C.C.; Atkinson, P.M.; Dearing, J.A. Extravagance in the commons: Resource exploitation and the frontiers of ecosystem service depletion in the Amazon estuary. Sci. Total Environ. 2016, 550, 6-16. [CrossRef]

5. $\quad$ Burgess, N.D.; Darrah, S.; Knight, S.; Danks, F.S. Approaches to Mapping Ecosystem Services; UNEP-WCMC: Cambridge, UK, 2016; ISBN 9789280735840. 
6. Burkhard, B.; Maes, J.; Potschin-Young, M.; Santos-Martín, F.; Geneletti, D.; Stoev, P.; Kopperoinen, L.; Adamescu, C.; Adem Esmail, B.; Arany, I.; et al. Mapping and assessing ecosystem services in the EU—Lessons learned from the ESMERALDA approach of integration. One Ecosyst. 2018, 3, e29153. [CrossRef]

7. Burkhard, B.; Kroll, F.; Nedkov, S.; Müller, F. Mapping ecosystem service supply, demand and budgets. Ecol. Indic. 2012, 21, 17-29. [CrossRef]

8. Daily, G.C. Introduction: What are ecosystem services? In Nature's Services: Societal Dependence On Natural Ecosystems; Daily, G.C., Ed.; Island Press: Washington, DC, USA, 1997; pp. 1-10.

9. Haas, J.; Ban, Y. Sentinel-1A SAR and sentinel-2A MSI data fusion for urban ecosystem service mapping. Remote Sens. Appl. Soc. Environ. 2017, 8, 41-53. [CrossRef]

10. Haase, D.; Larondelle, N.; Andersson, E.; Artmann, M.; Borgström, S.; Breuste, J.; Gomez-Baggethun, E.; Gren, Å.; Hamstead, Z.; Hansen, R.; et al. A quantitative review of urban ecosystem service assessments: Concepts, models, and implementation. Ambio 2014, 43, 413-433. [CrossRef] [PubMed]

11. Locke, D.H.; McPhearson, T. Urban areas do provide ecosystem services. Front. Ecol. Environ. 2018, 16, 203-205. [CrossRef]

12. McPhearson, T.; Andersson, E.; Elmqvist, T.; Frantzeskaki, N. Resilience of and through urban ecosystem services. Ecosyst. Serv. 2015, 12, 152-156. [CrossRef]

13. Elmqvist, T.; Setälä, H.; Handel, S.N.; van der Ploeg, S.; Aronson, J.; Blignaut, J.N.; Gómez-Baggethun, E.; Nowak, D.J.; Kronenberg, J.; de Groot, R. Benefits of restoring ecosystem services in urban areas. Curr. Opin. Environ. Sustain. 2015, 14, 101-108. [CrossRef]

14. Cord, A.F.; Brauman, K.A.; Chaplin-Kramer, R.; Huth, A.; Ziv, G.; Seppelt, R. Priorities to Advance Monitoring of Ecosystem Services Using Earth Observation. Trends Ecol. Evol. 2017, 32, 416-428. [CrossRef] [PubMed]

15. Haas, J.; Ban, Y. Urban Land Cover and Ecosystem Service Changes Based on Landsat TM and Sentinel-2A Data. IEEE J. Sel. Top. Appl. Earth Obs. Remote Sens. 2018, 11, 1-13. [CrossRef]

16. Kain, J.H.; Larondelle, N.; Haase, D.; Kaczorowska, A. Exploring local consequences of two land-use alternatives for the supply of urban ecosystem services in Stockholm year 2050. Ecol. Indic. 2016, 70, 615-629. [CrossRef]

17. Nowak, D.J.; Hoehn, R.E.; Bodine, A.R.; Greenfield, E.J.; O’Neil-Dunne, J. Urban forest structure, ecosystem services and change in Syracuse, NY. Urban Ecosyst. 2013, 19, 1-23. [CrossRef]

18. Luederitz, C.; Brink, E.; Gralla, F.; Hermelingmeier, V.; Meyer, M.; Niven, L.; Panzer, L.; Partelow, S.; Rau, A.L.; Sasaki, R.; et al. A review of urban ecosystem services: Six key challenges for future research. Ecosyst. Serv. 2015, 14, 98-112. [CrossRef]

19. Kremer, P.; Hamstead, Z.; Haase, D.; McPhearson, T.; Frantzeskaki, N.; Andersson, E.; Kabisch, N.; Larondelle, N.; Rall, E.L.; Voigt, A.; et al. Key insights for the future of urban ecosystem services research. Ecol. Soc. 2016, 21. [CrossRef]

20. Ayanu, Y.Z.; Conrad, C.; Nauss, T.; Wegmann, M.; Koellner, T. Quantifying and Mapping Ecosystem Services Supplies and Demands: A Review of Remote Sensing Applications. Environ. Sci. Technol. 2012, 46, 8529-8541. [CrossRef]

21. Ramirez-Reyes, C.; Brauman, K.A.; Chaplin-Kramer, R.; Galford, G.L.; Adamo, S.B.; Anderson, C.B.; Anderson, C.; Allington, G.R.H.; Bagstad, K.J.; Coe, M.T.; et al. Reimagining the potential of Earth observations for ecosystem service assessments. Sci. Total Environ. 2019, 665, 1053-1063. [CrossRef] [PubMed]

22. De Araujo Barbosa, C.C.; Atkinson, P.M.; Dearing, J.A. Remote sensing of ecosystem services: A systematic review. Ecol. Indic. 2015, 52, 430-443. [CrossRef]

23. Ren, Z.; Pu, R.; Zheng, H.; Zhang, D.; He, X. Spatiotemporal analyses of urban vegetation structural attributes using multitemporal Landsat TM data and field measurements. Ann. For. Sci. 2017, 74, 1-14. [CrossRef]

24. Dobbs, C.; Hernández-Moreno, Á.; Reyes-Paecke, S.; Miranda, M.D. Exploring temporal dynamics of urban ecosystem services in Latin America: The case of Bogota (Colombia) and Santiago (Chile). Ecol. Indic. 2018, 85, 1068-1080. [CrossRef]

25. Paul, C.K.; Mascarenhas, A.C. Remote Sensing in Development. Science 1981, 214, 139-145. [CrossRef] [PubMed]

26. Pettorelli, N.; Laurance, W.F.; O’Brien, T.G.; Wegmann, M.; Nagendra, H.; Turner, W. Satellite remote sensing for applied ecologists: Opportunities and challenges. J. Appl. Ecol. 2014, 51, 839-848. [CrossRef]

27. Kwok, R. Ecology's remote-sensing revolution. Nature 2018, 556, 137-138. [CrossRef] [PubMed]

28. Strauss, M. Planet Earth to get a daily selfie. Science 2017, 355, 782-783. [CrossRef] 
29. Li, P.; Feng, Z.; Xiao, C. Acquisition probability differences in cloud coverage of the available Landsat observations over mainland Southeast Asia from 1986 to 2015. Int. J. Digit. Earth 2018, 11, 437-450. [CrossRef]

30. Chang, J.; Qu, Z.; Xu, R.; Pan, K.; Xu, B.; Min, Y.; Ren, Y.; Yang, G.; Ge, Y. Assessing the ecosystem services provided by urban green spaces along urban center-edge gradients. Sci. Rep. 2017, 7, 1-9. [CrossRef]

31. Zhao, C.; Sander, H.A. Assessing the sensitivity of urban ecosystem service maps to input spatial data resolution and method choice. Landsc. Urban Plan. 2018, 175, 11-22. [CrossRef]

32. Kremer, P.; Hamstead, Z.A.; McPhearson, T. The value of urban ecosystem services in New York City: A spatially explicit multicriteria analysis of landscape scale valuation scenarios. Environ. Sci. Policy 2016, 62, 57-68. [CrossRef]

33. McPhearson, T.; Kremer, P.; Hamstead, Z.A. Mapping ecosystem services in New York City: Applying a social-ecological approach in urban vacant land. Ecosyst. Serv. 2013, 5, 11-26. [CrossRef]

34. Van der Biest, K.; Vrebos, D.; Staes, J.; Boerema, A.; Bodí, M.B.; Fransen, E.; Meire, P. Evaluation of the accuracy of land-use based ecosystem service assessments for different thematic resolutions. J. Environ. Manag. 2015, 156, 41-51. [CrossRef]

35. Wang, J.; Zhou, W.; Qian, Y.; Li, W.; Han, L. Quantifying and characterizing the dynamics of urban greenspace at the patch level: A new approach using object-based image analysis. Remote Sens. Environ. 2018, 204, 94-108. [CrossRef]

36. Wang, Y.; Li, X.; Zhang, Q.; Li, J.; Zhou, X. Projections of future land use changes: Multiple scenarios-based impacts analysis on ecosystem services for Wuhan city, China. Ecol. Indic. 2018, 94, 430-445. [CrossRef]

37. Greene, C.S.; Millward, A.A. Getting closure: The role of urban forest canopy density in moderating summer surface temperatures in a large city. Urban Ecosyst. 2017, 20, 141-156. [CrossRef]

38. Estoque, R.C.; Murayama, Y.; Myint, S.W. Effects of landscape composition and pattern on land surface temperature: An urban heat island study in the megacities of Southeast Asia. Sci. Total Environ. 2017, 577, 349-359. [CrossRef]

39. de Almeida, C.A.; Coutinho, A.C.; Esquerdo, J.C.D.M.; Adami, M.; Venturieri, A.; Diniz, C.G.; Dessay, N.; Durieux, L.; Gomes, A.R. High spatial resolution land use and land cover mapping of the Brazilian Legal Amazon in 2008 using Landsat-5/TM and MODIS data. Acta Amaz. 2016, 46, 291-302. [CrossRef]

40. Tyukavina, A.; Hansen, M.C.; Potapov, P.V.; Stehman, S.V.; Smith-Rodriguez, K.; Okpa, C.; Aguilar, R. Types and rates of forest disturbance in Brazilian Legal Amazon, 2000-2013. Sci. Adv. 2017, 3, 1-15. [CrossRef]

41. Tavares, P.; Beltrão, N.; Guimarães, U.; Teodoro, A. Integration of Sentinel-1 and Sentinel-2 for Classification and LULC Mapping in the Urban Area of Belém, Eastern Brazilian Amazon. Sensors 2019, 19, 1140. [CrossRef] [PubMed]

42. Whyte, A.; Ferentinos, K.P.; Petropoulos, G.P. A new synergistic approach for monitoring wetlands using Sentinels -1 and -2 data with object-based machine learning algorithms. Environ. Model. Softw. 2018, 104, 40-54. [CrossRef]

43. Wang, X.; Zhang, F.; Ding, J. Evaluation of water quality based on a machine learning algorithm and water quality index for the Ebinur Lake Watershed, China. Sci. Rep. 2017, 7, 1-18. [CrossRef]

44. Vafaei, S.; Soosani, J.; Adeli, K.; Fadaei, H.; Naghavi, H.; Pham, T.D.; Bui, D.T. Improving accuracy estimation of Forest Aboveground Biomass based on incorporation of ALOS-2 PALSAR-2 and Sentinel-2A imagery and machine learning: A case study of the Hyrcanian forest area (Iran). Remote Sens. 2018, 10, 172. [CrossRef]

45. Cian, F.; Marconcini, M.; Ceccato, P.; Giupponi, C. Flood depth estimation by means of high-resolution SAR images and LiDAR data. Nat. Hazards Earth Syst. Sci. 2018, 18, 1-25. [CrossRef]

46. Van Oudenhoven, A.P.E.; Martín-López, B.; Schröter, M.; de Groot, R. Advancing science on the multiple connections between biodiversity, ecosystems and people. Int. J. Biodivers. Sci. Ecosyst. Serv. Manag. 2018, 14, 127-131. [CrossRef]

47. Duan, J.; Wang, Y.; Fan, C.; Xia, B.; de Groot, R. Perception of Urban Environmental Risks and the Effects of Urban Green Infrastructures (UGIs) on Human Well-being in Four Public Green Spaces of Guangzhou, China. Environ. Manag. 2018, 62, 500-517. [CrossRef] [PubMed]

48. McPhearson, T.; Parnell, S.; Simon, D.; Gaffney, O.; Elmqvist, T.; Bai, X.; Roberts, D.; Revi, A. Scientists must have a say in the future of cities. Nature 2016, 538, 165-166. [CrossRef]

49. Hölscher, K.; Frantzeskaki, N.; McPhearson, T.; Loorbach, D. Tales of transforming cities: Transformative climate governance capacities in New York City, U.S. and Rotterdam, Netherlands. J. Environ. Manag. 2019, 231, 843-857. [CrossRef] [PubMed] 
50. McPhearson, T.; Pickett, S.T.A.; Grimm, N.B.; Niemelä, J.; Alberti, M.; Elmqvist, T.; Weber, C.; Haase, D.; Breuste, J.; Qureshi, S. Advancing Urban Ecology toward a Science of Cities. Bioscience 2016, 66, 198-212. [CrossRef]

51. McHale, M.R.; Pickett, S.T.A.; Barbosa, O.; Bunn, D.N.; Cadenasso, M.L.; Childers, D.L.; Gartin, M.; Hess, G.R.; Iwaniec, D.M.; McPhearson, T.; et al. The new global urban realm: Complex, connected, diffuse, and diverse social-ecological systems. Sustainability 2015, 7, 5211-5240. [CrossRef]

52. Van Oudenhoven, A.P.E.; Aukes, E.; Bontje, L.E.; Vikolainen, V.; Van Bodegom, P.M.; Slinger, J.H. 'Mind the Gap' between ecosystem services classification and strategic decision making. Ecosyst. Serv. 2018, 33, 77-88. [CrossRef]

53. Olander, L.; Polasky, S.; Kagan, J.S.; Johnston, R.J.; Wainger, L.; Saah, D.; Maguire, L.; Boyd, J.; Yoskowitz, D. So you want your research to be relevant? Building the bridge between ecosystem services research and practice. Ecosyst. Serv. 2017, 26, 170-182. [CrossRef]

54. Bibri, E.S.; Krogstie, J. Smart sustainable cities of the future: An extensive interdisciplinary literature review. Sustain. Cities Soc. 2017, 31, 183-212. [CrossRef]

55. Cortinovis, C.; Geneletti, D. Land Use Policy Ecosystem services in urban plans: What is there, and what is still needed for better decisions. Land Use Policy 2018, 70, 298-312. [CrossRef]

56. Gómez-Baggethun, E.; Barton, D.N. Classifying and valuing ecosystem services for urban planning. Ecol. Econ. 2013, 86, 235-245. [CrossRef]

57. Gaston, K.J.; Ávila-Jiménez, M.L.; Edmondson, J.L. Managing urban ecosystems for goods and services. J. Appl. Ecol. 2013, 50, 830-840. [CrossRef]

58. Uman, L.S. Information management for the busy practitioner: Systematic reviews and meta-analyses. J. Am. Acad. Child Adolesc. Psychiatry 2011, 20, 57-59. [CrossRef]

59. Moher, D.; Liberati, A.; Tetzlaff, J.; Altman, D. Preferred Reporting Items for Systematic Reviews and Meta-Analyses: The PRISMA Statement. Ann. Intern. Med. 2009, 6. [CrossRef]

60. Viana, J.; Santos, J.V.; Neiva, R.M.; Souza, J.; Duarte, L.; Teodoro, A.C.; Freitas, A. Remote sensing in human health: A 10-year bibliometric analysis. Remote Sens. 2017, 9, 1225. [CrossRef]

61. Ostoić, S.K.; van den Bosch, C.C.K. Exploring global scientific discourses on urban forestry. Urban For. Urban Green. 2015, 14, 129-138. [CrossRef]

62. Nardi, P.; Di Matteo, G.; Palahi, M.; Mugnozza, G.S. Structure and Evolution of Mediterranean Forest Research: A Science Mapping Approach. PLoS ONE 2016, 11, e0155016. [CrossRef]

63. Thorn, J.; Snaddon, J.; Waldron, A.; Kok, K.; Zhou, W.; Bhagwat, S.; Willis, K.; Petrokofsky, G. How effective are on-farm conservation land management strategies for preserving ecosystem services in developing countries? A systematic map protocol. Environ. Evid. 2015, 4, 1-12. [CrossRef]

64. Booth, A.; Sutton, A.; Papaioannou, D. Systematic Approaches to a Successful Literature Review, 2nd ed.; SAGE Publications: Thousand Oaks, CA, USA, 2016; ISBN 978-1-4739-1245-8.

65. Neuenschwander, N.; Wissen Hayek, U.; Grêt-Regamey, A. Integrating an urban green space typology into procedural 3D visualization for collaborative planning. Comput. Environ. Urban Syst. 2014, 48, 99-110. [CrossRef]

66. Holt, A.R.; Mears, M.; Maltby, L.; Warren, P. Understanding spatial patterns in the production of multiple urban ecosystem services. Ecosyst. Serv. 2015, 16, 33-46. [CrossRef]

67. Cai, Y.B.; Zhang, H.; Pan, W.B.; Chen, Y.H.; Wang, X.R. Land use pattern, socio-economic development, and assessment of their impacts on ecosystem service value: Study on natural wetlands distribution area (NWDA) in Fuzhou city, southeastern China. Environ. Monit. Assess. 2013, 185, 5111-5123. [CrossRef]

68. Casado-Arzuaga, I.; Onaindia, M.; Madariaga, I.; Verburg, P.H. Mapping recreation and aesthetic value of ecosystems in the Bilbao Metropolitan Greenbelt (northern Spain) to support landscape planning. Landsc. Ecol. 2014, 29, 1393-1405. [CrossRef]

69. De Mola, U.L.; Ladd, B.; Duarte, S.; Borchard, N.; La Rosa, R.A.; Zutta, B. On the use of hedonic price indices to understand ecosystem service provision from urban green space in five Latin American megacities. Forests 2017, 8, 478. [CrossRef]

70. Wang, H.-F.; Qureshi, S.; Qureshi, B.A.; Qiu, J.-X.; Friedman, C.R.; Breuste, J.; Wang, X.-K. A multivariate analysis integrating ecological, socioeconomic and physical characteristics to investigate urban forest cover and plant diversity in Beijing, China. Ecol. Indic. 2016, 60, 921-929. [CrossRef] 
71. de la Barrera, F.; Rubio, P.; Banzhaf, E. The value of vegetation cover for ecosystem services in the suburban context. Urban For. Urban Green. 2016, 16, 110-122. [CrossRef]

72. Richards, D.R.; Edwards, P.J. Quantifying street tree regulating ecosystem services using Google Street View. Ecol. Indic. 2017, 77, 31-40. [CrossRef]

73. Lehmann, I.; Mathey, J.; Rößler, S.; Bräuer, A.; Goldberg, V. Urban vegetation structure types as a methodological approach for identifying ecosystem services-Application to the analysis of micro-climatic effects. Ecol. Indic. 2014, 42, 58-72. [CrossRef]

74. Bottalico, F.; Travaglini, D.; Chirici, G.; Garfi, V.; Giannetti, F.; De Marco, A.; Fares, S.; Marchetti, M.; Nocentini, S.; Paoletti, E.; et al. A spatially-explicit method to assess the dry deposition of air pollution by urban forests in the city of Florence, Italy. Urban For. Urban Green. 2017, 27, 221-234. [CrossRef]

75. Tigges, J.; Churkina, G.; Lakes, T. Modeling above-ground carbon storage: A remote sensing approach to derive individual tree species information in urban settings. Urban Ecosyst. 2017, 20, 97-111. [CrossRef]

76. Grunwald, L.; Heusinger, J.; Weber, S. A GIS-based mapping methodology of urban green roof ecosystem services applied to a Central European city. Urban For. Urban Green. 2017, 22, 54-63. [CrossRef]

77. Zhang, Y.; Murray, A.T.; Turner, B.L. Optimizing green space locations to reduce daytime and nighttime urban heat island effects in Phoenix, Arizona. Landsc. Urban Plan. 2017, 165, 162-171. [CrossRef]

78. Kopecká, M.; Szatmári, D.; Rosina, K. Analysis of Urban Green Spaces Based on Sentinel-2A: Case Studies from Slovakia. Land 2017, 6, 25. [CrossRef]

79. Lafortezza, R.; Giannico, V. Combining high-resolution images and LiDAR data to model ecosystem services perception in compact urban systems. Ecol. Indic. 2017, 87-98. [CrossRef]

80. Calderón-Contreras, R.; Quiroz-Rosas, L.E. Analysing scale, quality and diversity of green infrastructure and the provision of Urban Ecosystem Services: A case from Mexico City. Ecosyst. Serv. 2017, 23, 127-137. [CrossRef]

81. Haas, J.; Ban, Y.F. Mapping and monitoring urban ecosystem services using high-resolution satellite data. IEEE J. Sel. Top. Appl. Earth Obs. Remote Sens. 2017, 10, 669-680. [CrossRef]

82. Liu, Y. Dynamic evaluation on ecosystem service values of urban rivers and lakes: A case study of Nanchang City, China. Aquat. Ecosyst. Heal. Manag. 2014, 17, 161-170. [CrossRef]

83. Antognelli, S.; Vizzari, M. Landscape liveability spatial assessment integrating ecosystem and urban services with their perceived importance by stakeholders. Ecol. Indic. 2017, 72, 703-725. [CrossRef]

84. Singh, K.K.; Bianchetti, R.A.; Chen, G.; Meentemeyer, R.K. Assessing effect of dominant land-cover types and pattern on urban forest biomass estimated using LiDAR metrics. Urban Ecosyst. 2017, 20, 265-275. [CrossRef]

85. Peng, J.; Zhao, M.; Guo, X.; Pan, Y.; Liu, Y. Spatial-temporal dynamics and associated driving forces of urban ecological land: A case study in Shenzhen City, China. Habitat Int. 2017, 60, 81-90. [CrossRef]

86. Richards, D.R.; Passy, P.; Oh, R.R.Y. Impacts of population density and wealth on the quantity and structure of urban green space in tropical Southeast Asia. Landsc. Urban Plan. 2017, 157, 553-560. [CrossRef]

87. Van de Voorde, T. Spatially explicit urban green indicators for characterizing vegetation cover and public green space proximity: A case study on Brussels, Belgium. Int. J. Digit. Earth 2016, 10, 798-813. [CrossRef]

88. Banzhaf, E.; Kollai, H. Monitoring the urban tree cover for urban ecosystem services-The case of Leipzig, Germany. Int. Arch. Photogramm. Remote Sens. Spat. Inf. Sci. ISPRS Arch. 2015, 40, 301-305. [CrossRef]

89. Larondelle, N.; Haase, D.; Kabisch, N. Mapping the diversity of regulating ecosystem services in European cities. Glob. Environ. Chang. 2014, 26, 119-129. [CrossRef]

90. Kim, G.; Miller, P.A.; Nowak, D.J. Assessing urban vacant land ecosystem services: Urban vacant land as green infrastructure in the City of Roanoke, Virginia. Urban For. Urban Green. 2015, 14, 519-526. [CrossRef]

91. Behling, R.; Bochow, M.; Foerster, S.; Roessner, S.; Kaufmann, H. Automated GIS-based derivation of urban ecological indicators using hyperspectral remote sensing and height information. Ecol. Indic. 2015, 48, 218-234. [CrossRef]

92. Goldenberg, R.; Kalantari, Z.; Cvetkovic, V.; Mörtberg, U.; Deal, B.; Destouni, G. Distinction, quantification and mapping of potential and realized supply-demand of flow-dependent ecosystem services. Sci. Total Environ. 2017, 593-594, 599-609. [CrossRef]

93. Chen, A.; Yao, X.A.; Sun, R.; Chen, L. Effect of urban green patterns on surface urban cool islands and its seasonal variations. Urban For. Urban Green. 2014, 13, 646-654. [CrossRef]

94. Fusaro, L.; Marando, F.; Sebastiani, A.; Capotorti, G.; Blasi, C.; Copiz, R.; Congedo, L.; Munafò, M.; Ciancarella, L.; Manes, F. Mapping and assessment of PM10 and O3 removal by woody vegetation at urban and regional level. Remote Sens. 2017, 9, 791. [CrossRef] 
95. Manes, F.; Marando, F.; Capotorti, G.; Blasi, C.; Salvatori, E.; Fusaro, L.; Ciancarella, L.; Mircea, M.; Marchetti, M.; Chirici, G.; et al. Regulating Ecosystem Services of forests in ten Italian Metropolitan Cities: Air quality improvement by PM10and O3removal. Ecol. Indic. 2016, 67, 425-440. [CrossRef]

96. Manes, F.; Silli, V.; Salvatori, E.; Incerti, G.; Galante, G.; Fusaro, L.; Perrino, C. Urban ecosystem services: Tree diversity and stability of PM10 removal in the metropolitan area of Rome. Annali di Botanica 2014, 4, 19-26. [CrossRef]

97. Manes, F.; Salvatori, E. Ecosystem services of urban trees: The case of rome. Agrochimica 2014, 58, $222-233$. [CrossRef]

98. Ala-Hulkko, T.; Kotavaara, O.; Alahuhta, J.; Helle, P.; Hjort, J. Introducing accessibility analysis in mapping cultural ecosystem services. Ecol. Indic. 2016, 66, 416-427. [CrossRef]

99. Bai, X.; Dawson, R.J.; Ürge-Vorsatz, D.; Delgado, G.C.; Salisu Barau, A.; Dhakal, S.; Dodman, D.; Leonardsen, L.; Masson-Delmotte, V.; Roberts, D.C.; et al. Six research priorities for cities and climate change. Nature 2018, 555, 23-25. [CrossRef] [PubMed]

100. Li, C.; Zhu, X.; Wei, Y.; Cao, S.; Guo, X.; Yu, X.; Chang, C. Estimating apple tree canopy chlorophyll content based on Sentinel-2A remote sensing imaging. Sci. Rep. 2018, 8, 1-10. [CrossRef]

101. Poursanidis, D.; Chrysoulakis, N. Remote Sensing Applications: Society and Environment Remote Sensing, natural hazards and the contribution of ESA Sentinels missions. Remote Sens. Appl. Soc. Environ. 2017, 6, 25-38. [CrossRef]

102. Li, J.; Roy, D.P. A Global Analysis of Sentinel-2A, Sentinel-2B and Landsat-8 Data Revisit Intervals and Implications for Terrestrial Monitoring. Remote Sens. 2017, 9, 902. [CrossRef]

103. Popkin, G. US government considers charging for popular Earth-observing data. Nature 2018, 556, 417-418. [CrossRef]

104. Reiche, J.; Lucas, R.; Mitchell, A.L.; Verbesselt, J.; Hoekman, D.H.; Haarpaintner, J.; Kellndorfer, J.M.; Rosenqvist, A.; Lehmann, E.A.; Woodcock, C.E.; et al. Combining satellite data for better tropical forest monitoring. Nat. Clim. Chang. 2016, 6, 120-122. [CrossRef]

105. Joshi, N.; Baumann, M.; Ehammer, A.; Fensholt, R.; Grogan, K.; Hostert, P.; Jepsen, M.R.; Kuemmerle, T.; Meyfroidt, P.; Mitchard, E.T.A.; et al. A review of the application of optical and radar remote sensing data fusion to land use mapping and monitoring. Remote Sens. 2016, 8, 70. [CrossRef]

106. Nery, T.; Sadler, R.; Solis-Aulestia, M.; White, B.; Polyakov, M.; Chalak, M. Comparing supervised algorithms in Land Use and Land Cover classification of a Landsat time-series. In Proceedings of the 2016 IEEE International Geoscience and Remote Sensing Symposium (IGARSS), Beijing, China, 10-15 July 2016; pp. 5165-5168.

107. Thi, H.; Nguyen, T.; Doan, T.M.; Radeloff, V. Applying Random Forest Classification To Map Land Use/Land Cover Using Landsat 8 Oli. ISPRS Int. Arch. Photogramm. Remote Sens. 2018, XLII-3/W4, 363-367.

108. Deus, D. Integration of ALOS PALSAR and Landsat Data for Land Cover and Forest Mapping in Northern Tanzania. Land 2016, 5, 43. [CrossRef]

109. Maxwell, A.E.; Warner, T.A.; Fang, F. Implementation of machine-learning classification in remote sensing: An applied review. Int. J. Remote Sens. 2018, 39, 2784-2817. [CrossRef]

110. Alonzo, M.; McFadden, J.P.; Nowak, D.J.; Roberts, D.A. Mapping urban forest structure and function using hyperspectral imagery and lidar data. Urban For. Urban Green. 2016, 17, 135-147. [CrossRef]

111. Sasaki, T.; Imanishi, J.; Fukui, W.; Morimoto, Y. Fine-scale characterization of bird habitat using airborne LiDAR in an urban park in Japan. Urban For. Urban Green. 2016, 17, 16-22. [CrossRef]

112. Alam, M.; Dupras, J.; Messier, C. A framework towards a composite indicator for urban ecosystem services. Ecol. Indic. 2016, 60, 38-44. [CrossRef]

113. Baró, F.; Palomo, I.; Zulian, G.; Vizcaino, P.; Haase, D.; Gómez-Baggethun, E. Mapping ecosystem service capacity, flow and demand for landscape and urban planning: A case study in the Barcelona metropolitan region. Land Use Policy 2016, 57, 405-417. [CrossRef]

(C) 2019 by the authors. Licensee MDPI, Basel, Switzerland. This article is an open access article distributed under the terms and conditions of the Creative Commons Attribution (CC BY) license (http://creativecommons.org/licenses/by/4.0/). 